\title{
The Effects of the Multidisciplinary Team Approach on Blood Transfusion
}

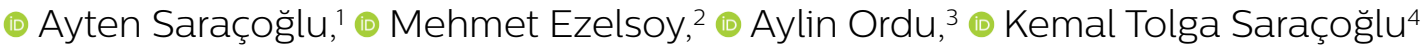

'Department of Anesthesiology and
Intensive Care, Marmara University
Faculty of Medicine, İstanbul, Turkey
${ }^{2}$ Department of Cardiovascular
Surgery, Bilim University Faculty of
Medicine, İstanbul, Turkey
${ }^{3}$ Department of Infectious Diseases
and Clinical Microbiology, Bilim
University Faculty of Medicine,
İstanbul, Turkey
4Clinic of Anesthesiology and
Intensive Care, Health Sciences
University Kartal Dr. Lürfi Kırdar
Training and Research Hospital,
İstanbul, Turkey
Submitted: 16.03.2019
Accepted: 18.04.2019

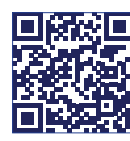

Keywords: Blood

transfusion; cardiac surgical procedures; education.

This work is licensed under a Creative Commons Attribution-NonCommercial 4.0 International License.

\begin{abstract}
Objective: The Joint Commission and the American Medical Association-Convened Physician Consortium for Performance Improvement reported that the blood transfusions are among the top five overused treatments in modern medicine. Optimal management of blood transfusion is one of the most important factors that increase patient safety, and special education is increasing all over the world in this regard. In this retrospective cohort study, our goal was to investigate the effects of periodic consensus meetings and training on perioperative blood transfusion by a team of different branches of medicine.
\end{abstract}

Methods: Patients over the age of 18 undergoing cardiac surgery and required blood transfusion were included in this study. The transfusions were calculated cumulatively; the change concerning years was determined, as well as side effects and complications associated with transfusion. Patients' cardiac reserves, laboratory values, anticoagulant drug use frequency, transfused blood volume, complications and mortality rates were recorded. The types of surgery, reexploration rate, length of intensive care and hospital stay were recorded.

Results: Patients' age, BMI, comorbidity ratio and antimicrobial drug use did not differ between years $(p>0.05)$. The length of intensive care and hospital stay, amount of bleeding, mortality rate did not differ ( $p>0.05)$. Cardiopulmonary Bypass time and Cross Clamp time in 2016, were significantly higher $(p<0.05)$ than in 2014 and 2015 . The amount of blood transfusion did not differ significantly $(p>0.05)$. Besides, after 2014 , an increase was observed in platelet transfusion. The change in $\mathrm{Hb}, \mathrm{Htc}$, platelet and INR did not differ significantly in the pre-postoperative period.

Conclusion: Training on the restrictive use of blood products did not have a positive influence on blood transfusion in our study. It has been demonstrated that there are challenges in sufficiently transferring the knowledge to the clinical environment.

\section{INTRODUCTION}

Blood transfusion has been reported to be the most commonly performed procedure across the U.S.A. hospitals. [1] According to the data of the Joint Commission, blood transfusion is one of the top five overused medical procedures. ${ }^{[2]}$ Blood transfusions have been associated with renal insufficiency, prolonged intubation, neurological complications, increased risk of infection and mortality. ${ }^{[3]}$

Patient blood management (PBM) is important as it provides benefits both regarding quality improvement and patient safety. Management of hemorrhage is challenging in case of cardiac surgeries because of the aging population, complicated procedures, increased comorbidities and increased use of anticoagulants and antiplatelet agents. ${ }^{[4,5]}$ The risk of bleeding is high, and in cases of bleeding, blood transfusion is a frequently preferred treatment choice. However, accumulated evidence on the relationship between blood transfusion and adverse events is alarming. ${ }^{[6-9]}$ Furthermore, reduced transfusion of all blood products with appropriate bleeding management strategies has been associated with morbidity, mortality and cost.

According to the definition of the Society for the Advancement of Blood Management, patient blood management is "the timely application of evidence-based medical and surgical concepts designed to maintain hemoglobin concentration, optimize hemostasis and minimize blood loss in an effort to improve patient outcome". ${ }^{[10]}$ It has been indicated that successful implementation of PBM reduces perioperative blood loss and transfusion requirements, and thus, positively affects perioperative morbidity, mortality, hospital costs, and duration of hospital stay. 
[11,12] PBM should be conducted by a multidisciplinary team, who works in harmony and is supported institution-wide. [13] According to the American Society of Extracorporeal Technology (AmSECT), the combination of the multidisciplinary approach, institutional support and transfusion algorithms with point-of-care testing limit blood transfusion in cardiac surgeries, making optimal patient care possible. [14] A multidisciplinary approach can minimize errors and enable continuous maintenance of high-quality patient care. ${ }^{[15]}$

At our hospital, we aimed to decrease perioperative transfusion rate through the multidisciplinary approach. For this purpose, a commission consisting of specialists from the departments of anesthesiology, intensive care, cardiovascular surgery, and blood bank unit, as well as representatives from hospital administration, was established and held monthly meetings to develop strategies related to PBM. This retrospective cohort study aims to investigate the impacts of periodical consensus meetings and training conducted by a team involving representatives from different medical disciplines on perioperative blood transfusion.

\section{MATERIALS AND METHODS}

Following the Ethics Committee (No: 44I40529/20I7-64, date: 30.05.2017) approval, between January 2014 and December 2016, patients over the age of 18 who underwent cardiac surgery and had blood transfusion were included in this study. This research was conducted in accordance with the principles set forth in the Helsinki Declaration 2008. The transfusions were calculated cumulatively; the change concerning years was determined, as well as side effects and complications associated with transfusion. $\mathrm{Pa}$ tients' cardiac reserves, preoperative and postoperative laboratory values, anticoagulant drug use frequency, transfused blood volume, complications and mortality rates were recorded. The types of surgery, reexploration rate, length of intensive care and hospital stay were recorded.

Three years ago, a multidisciplinary team consisting of an anesthesiologist, a hospital manager, a hematologist, a blood bank accountant, a cardiovascular surgeon, a chief anesthesia technician, and an operating room (OR) nurse was founded. This team met once every three months, and during the meetings, team members evaluated the total Red Blood Cell (RBC), Fresh Frozen Plasma (FFP), cryoprecipitate and platelet amount used during cardiac surgeries. They also addressed how to reduce transfusion rates and specified measures. Protocols and algorithms were composed for patients receiving antithrombotic agents or massive transfusion and shared with anesthesiologists, operating room technicians, nurses and cardiovascular surgeons. Recent guidelines on blood product consumption were discussed during the meetings and decisions were taken regarding the treatment of preoperative anemia. Patients were evaluated for a three-year period between 2014 and 2016. Patient's demographic data, comorbidities, use of antithrombotic agents, Cardiopulmonary Bypass
(CPB) time, Cross Clamp (Cx) time, extubation time, total hemorrhage, and duration of stay at the hospital and intensive care unit (ICU) were recorded. Also, their preoperative and postoperative Hemoglobin $(\mathrm{Hb})$ and Hematocrit (Htc) values were assessed and compared.

\section{Statistical Analysis}

The SPSS 22.0 program was used for the analysis of the study data. The descriptive statistics employed in this study were mean, standard deviation, median, minimum, maximum, frequency, and ratio. The Kolmogorov-Smirnov test was used to measure the distribution of variables. The Mann-Whitney $U$ test was used to analyze quantitative independent data and the Chi-square test was used to assess the qualitative independent data. In cases where the Chi-square conditions were not met, the Fisher test was used for the qualitative data. $A$ value of $p<0.05$ was considered statistically significant.

\section{RESULTS}

Data belonging to 494 patients were analyzed. Patients' ages, Body Mass Index (BMI), Ejection Fraction (EF) value, extubation time, Chronic Obstructive Pulmonary Disease (COPD), Diabetes Mellitus (DM), Hypertension (HT) ratio, antimicrobial drug use, stay at hospital and ICU, hemorrhage rate and hospital mortality did not differ significantly between the years 2014, 2015 and 2016 ( $p>0.05$, Table I).

In 2016, CPB time and Cx time were significantly longer than in 2014 and $2015(p<0.05)$. CPB time and $C x$ time were significantly longer in 2015 than in $2014(p<0.05$, Table I).

There was no significant difference between 2014, 2015 and 2016 regarding the amounts of transfused RBC, FFP, apheresis platelets and cryoprecipitate ( $p>0.05)$. In 2015, the random platelet transfusion rate was significantly higher than the rate in 2014 and $2016(p<0.001$, Table I). However, there was no significant difference between 2014 and 2015 regarding the amount of pooled platelet transfused.

There was no significant difference between years regarding the change between preoperative and postoperative $\mathrm{Hb}, \mathrm{Htc}$, platelet and INR levels ( $p>0.05)$. When each year was separately evaluated, there was a significant decrease in $\mathrm{Hb}$, Htc, platelet, and INR levels in the postoperative period as compared to the preoperative period $(p<0.05$, Table 2).

In 2014, the postoperative platelet level was significantly higher than in 2015 and $2016(p<0.05)$. However, the postoperative platelet level did not show a significant difference between the years 2015 and 2016 ( $p>0.05$ ).

In 2016, the postoperative INR level was significantly lower as compared to 2015 and $2014(p<0.05)$. However, the postoperative INR level did not show a significant difference between the years 2014 and 2015 ( $p>0.05$ ). 
Table I. The correlation between comorbidities, complications, transfusion and mortality rates according to last three years

\begin{tabular}{|c|c|c|c|c|c|}
\hline & 2014 (Mean $\pm S D)$ & 2015 (Mean $\pm S D)$ & 2016 (Mean $\pm S D)$ & $\mathbf{p}$ & \\
\hline Age (years) & $66.7 \pm 10.1$ & $66.3 \pm 10.1$ & $63.6 \pm 65.0$ & 0.067 & K \\
\hline Body mass index & $26.7 \pm 2.2$ & $26.7 \pm 1.8$ & $26.6 \pm 1.9$ & 0.834 & K \\
\hline Ejection fraction (\%) & $51.8 \pm 4.9$ & $50.8 \pm 4.9$ & $50.1 \pm 5.0$ & 0.172 & K \\
\hline Cardiopulmonary bypass time (min) & $76.8 \pm 23.2$ & $90.8 \pm 29.3$ & $101.8 \pm 37.6$ & 0.000 & K \\
\hline Cross clamp time (min) & $50.9 \pm 18.1$ & $70.6 \pm 23.2$ & $78.9 \pm 28.7$ & 0.000 & K \\
\hline Extubation time $(\mathrm{h})$ & $6.5 \pm 1.4$ & $6.5 \pm 1.3$ & $6.4 \pm 1.3$ & 0.878 & K \\
\hline \multicolumn{6}{|c|}{ Chronic obstructive pulmonary disease, $\mathrm{n}(\%)$} \\
\hline$(-)$ & $25(78.1)$ & $122(78.2)$ & $24 I(78.8)$ & 0.989 & $X^{2}$ \\
\hline$(+)$ & $7(21.9)$ & $34(21.8)$ & $65(21.2)$ & & \\
\hline \multicolumn{6}{|l|}{ Diabetes Mellitus, n (\%) } \\
\hline$(-)$ & $20(62.5)$ & $101(64.7)$ & $202(66.0)$ & 0.905 & $X^{2}$ \\
\hline$(+)$ & $12(37.5)$ & $55(35.3)$ & $104(34.0)$ & & \\
\hline \multicolumn{6}{|l|}{ Hypertension, n (\%) } \\
\hline$(-)$ & $23(71.9)$ & $110(70.5)$ & $216(70.6)$ & 0.988 & $X^{2}$ \\
\hline$(+)$ & $9(28.1)$ & $46(29.5)$ & $90(29.4)$ & & \\
\hline \multicolumn{6}{|l|}{ Antitrombotic agent, n (\%) } \\
\hline$(-)$ & $16(50.0)$ & $76(48.7)$ & $159(52.0)$ & 0.833 & $X^{2}$ \\
\hline$(+)$ & $16(50.0)$ & $79(50.6)$ & $147(48.0)$ & & \\
\hline \multicolumn{6}{|l|}{ Intensive care unit stay (days), n (\%) } \\
\hline I gün & $25(78.1)$ & $122(78.2)$ & $247(80.7)$ & 0.794 & $X^{2}$ \\
\hline 2 gün & 7 (2I.9) & $33(21.2)$ & $59(19.3)$ & & \\
\hline 4 gün & $0(0.0)$ & I (0.6) & $0(0.0)$ & & \\
\hline \multicolumn{6}{|l|}{ Bleeding, n (\%) } \\
\hline$(-)$ & 31 (96.9) & $150(96.2)$ & $297(97.1)$ & $>0.05$ & $X^{2}$ \\
\hline$(+)$ & I (3.I) & $6(3.8)$ & $9(2.9)$ & & \\
\hline Total amount of bleeding & $468.4 \pm 249.4$ & $457.3 \pm 255.5$ & $444.8 \pm 229.8$ & 0.808 & K \\
\hline \multicolumn{6}{|l|}{ Hospital stay (days), n (\%) } \\
\hline 7 days & $24(75.0)$ & II5 (73.7) & $234(76.5)$ & 0.831 & $X^{2}$ \\
\hline 8 days & $8(25.0)$ & $37(23.7)$ & $70(22.9)$ & & \\
\hline 9 days & $0(0.0)$ & $3(1.9)$ & I (0.3) & & \\
\hline Mortality rate, n (\%) & $I(3.1)$ & $2(1.3)$ & $2(0.7)$ & $>0.05$ & \\
\hline Red blood cell & $4.8 \pm 11.6$ & $2.9 \pm 2.3$ & $3.5 \pm 3.4$ & 0.055 & $\mathrm{~K}$ \\
\hline Not transfused, n (\%) & $3(9.4)$ & $19(12.2)$ & $29(9.5)$ & 0.640 & $X^{2}$ \\
\hline Transfused, n (\%) & $29(90.6)$ & I 37 (87.8) & $277(90.5)$ & & \\
\hline Fresh frozen plasma & $4.3 \pm 7.8$ & $2.7 \pm 1.9$ & $3.3 \pm 2.5$ & 0.060 & $\mathrm{~K}$ \\
\hline Not transfused, n (\%) & $14(43.8)$ & $73(46.8)$ & $121(39.5)$ & 0.322 & $X^{2}$ \\
\hline Transfused, n (\%) & $18(56.3)$ & $83(53.2)$ & $185(60.5)$ & & \\
\hline Random donor platelet & $9.4 \pm 8.5$ & $12.8 \pm 4.2$ & $7.3 \pm 3.6$ & 0.052 & $\mathrm{~K}$ \\
\hline Not transfused, n (\%) & $27(84.4)$ & 149 (95.5) & $280(91.5)$ & $<0.001$ & $X^{2}$ \\
\hline Transfused, n (\%) & $5(15.6)$ & $7(4.5)$ & $54(17.6)$ & & \\
\hline Apheresis platelet & $1.5 \pm 0.7$ & $1.5 \pm 0.7$ & $1.0 \pm 0.0$ & 0.086 & $\mathrm{~K}$ \\
\hline Not transfused, n (\%) & $30(93.8)$ & I54 (98.7) & $297(97.1)$ & $>0.05$ & $X^{2}$ \\
\hline Transfused, n (\%) & $2(6.3)$ & $2(1.3)$ & $9(2.9)$ & & \\
\hline Cryoprecipitate & $7.5 \pm 2.1$ & $5.0 \pm 1.4$ & $7.8 \pm 3.6$ & 0.323 & $\mathrm{~K}$ \\
\hline Not transfused, n (\%) & $30(93.8)$ & I54 (98.7) & $298(97.4)$ & $>0.05$ & $X^{2}$ \\
\hline Transfused, n (\%) & $2(6.3)$ & $2(1.3)$ & $8(2.6)$ & & \\
\hline
\end{tabular}

\section{DISCUSSION}

Within the scope of this study, a multidisciplinary team consisting of physicians and managers from different clinical departments was established and held meetings at reg- ular intervals to restrict blood transfusions. As a result, there has been a change in the incidence of blood transfusion at the cardiac surgery department of our hospital during three years period. We analyzed the factors that might have influenced this change. 
Table 2. The change in hemoglobin, hematocrit, platelet and international normalized ratio levels according to the years

\begin{tabular}{|c|c|c|c|c|c|c|c|c|}
\hline & \multicolumn{2}{|c|}{2014} & \multicolumn{2}{|c|}{2015} & \multicolumn{2}{|c|}{2016} & \multirow[t]{2}{*}{$\mathbf{p}$} & \\
\hline & Mean $\pm S D$ & Median & Mean $\pm S D$ & Median & Mean $\pm S D$ & Median & & \\
\hline \multicolumn{9}{|l|}{ Hemoglobin (g/dL) } \\
\hline Preoperative & $13.7 \pm 1.8$ & 13.7 & $13.6 \pm 1.5$ & 13.8 & $13.1 \pm 1.7$ & 13.1 & 0.052 & $\mathrm{~K}$ \\
\hline Postoperative & $10.5 \pm 1.5$ & 10.4 & $10.5 \pm 1.1$ & 10.5 & $10.3 \pm 1.0$ & 10.2 & 0.102 & $\mathrm{~K}$ \\
\hline Pre/post change $(p)$ & 0.000 & w & & 0.000 & w & & 0.000 & w \\
\hline \multicolumn{9}{|l|}{ Hematocrit (\%) } \\
\hline Preoperative & $39.4 \pm 4.9$ & 39.1 & $38.9 \pm 3.8$ & 39.3 & $38.5 \pm 4.6$ & 38.8 & 0.374 & K \\
\hline Postoperative & $30.7 \pm 4.2$ & 30.0 & $30.4 \pm 3.2$ & 30.2 & $30.3 \pm 2.9$ & 30.2 & 0.984 & K \\
\hline Pre/post change $(p)$ & 0.000 & w & 0.000 & w & 0.000 & w & & \\
\hline \multicolumn{9}{|l|}{ Platelet } \\
\hline Preoperative & $248.2 \pm 86.6$ & 231.0 & $234.6 \pm 73.7$ & 233.0 & $236.7 \pm 71.4$ & 224.0 & 0.909 & K \\
\hline Postoperative & $210.9 \pm 82.4$ & 194.5 & $\mid 70.1 \pm 67.4$ & 159.5 & $\mid 78.0 \pm 61.3$ & 170.0 & 0.014 & $\mathrm{~K}$ \\
\hline Pre/post change $(p)$ & 0.002 & w & & 0.000 & w & & 0.000 & w \\
\hline \multicolumn{9}{|c|}{ International normalized ratio } \\
\hline Preoperative & $1.01 \pm 0.17$ & 1.08 & $1.08 \pm 1.76$ & 1.06 & $1.05 \pm 0.10$ & 1.03 & 0.060 & K \\
\hline Postoperative & $1.24 \pm 0.27$ & 1.23 & $1.25 \pm 1.91$ & 1.23 & $1.20 \pm 0.17$ & 1.18 & 0.000 & $\mathrm{~K}$ \\
\hline Pre/post change $(p)$ & 0.001 & w & & 0.000 & w & & 0.000 & w \\
\hline
\end{tabular}

KKruskal-wallis (Mann-whitney u test); 'Wilcoxon test.

The CPB time and Cx time gradually increased in years, which may be associated with surgical factors. We believe that the diversity of surgeons and new surgeons that recently took part in the team may have contributed to this issue. Besides, an increasing number of complex surgeries may be another contributing factor. Ultimately, increased CPB and Cx time impairs erythrocyte rheology and increases the need for transfusion. ${ }^{[16]}$ Moreover, in case of extended CPB, shear-mediated platelet dysfunction brings about other problems. ${ }^{\left[{ }^{17]}\right.}$ It was reported in previous studies that patients with prolonged $\mathrm{Cx}$ time had an increased incidence of blood transfusion. ${ }^{[18,19]}$ We were not able to reduce the total volume of blood and blood products transfused. However, it is obvious that the effects of everincreasing CPB and Cx time had a significant role in that failure, and we attribute the non-increase in the amount of transfusion to the extension in CPB and Cx time. The total volume of blood product transfusion did not differ significantly except for the increase in the amount of pooled platelets. It also demonstrates the positive effects of teamwork. Our PBM studies are going on with a future goal to reduce the amount of total blood transfusion.

Managing preoperative anemia through early diagnosis methods is one of the guiding principles of PBM, whereas anemia is actively treated, physiological tolerance of anemia can be reduced by minimizing oxygen consumption. Preoperative anemia has been reported to be associated with a prolonged hospital stay, higher incidence of complications, increased need for transfusion, and elevated mortality rates. ${ }^{[20]}$ At our cardiac surgery unit, we initiate oral or IV iron preparations for patients, who are diagnosed with anemia in the preoperative period. One of the major objectives of our meetings was to raise awareness among the surgical team about this phenomenon. Another PBM strategy includes optimization of coagulopathy, which involves determining the current coagulation status of a patient, assessing the drugs affecting the coagulation status, correcting abnormalities and rapidly and assessing the cause of the bleeding if present. In this context, a treatment approach algorithm was created at our unit for patients using anticoagulant agents, and it was shared with the surgical team. Our cardiac surgery unit also established a protocol for massive hemorrhage and successfully applied it, especially in the management of complex surgeries. Also, during the meetings, physicians were asked to comply with this principle by ensuring the use of surgical techniques that are sensitive enough to reduce the loss of blood. Furthermore, intraoperative blood conservation techniques, such as cell saver, and autologous protection modalities, have been frequently employed.

Whitney et al. ${ }^{[2]}$ included the representatives of the following departments in their multidisciplinary team built to reduce the need for blood transfusion: anesthesiology, transfusion medicine; the center for quality, safety, and risk prevention; and the center for research and innovation and system safety. The results of Whitney et al.'s study showed that a multidisciplinary team focused on the ordering, shipment, and storage of blood products can significantly reduce $\mathrm{RBC}$ transfusion rate and associated costs through quality and process improvement methods. Different from the team of Whitney et al., the team we formed at our hospital consisted of a hematologist, a blood bank manager, a cardiovascular surgeon, a hospital manager, a quality developer, an anesthesia technician, and a responsible operating room nurse as well as an anesthesiologist. Financial concerns of hospital managers 
may bring about major difficulties in taking patient blood management a step further. Thus, we included hospital managers in our team and tried to convince them about various important issues through cost analyses. There had been periodical morbidity and mortality meetings at our hospital. A consensus was established at our clinic about the routine use of bleeding monitoring methods, such as thromboelastography and drugs like tranexamic acid. On the other hand, despite the benefits of PBM, many obstacles and difficulties, especially those resulting from lack of knowledge, limit the transfer of PBM guidelines into clinical practice. ${ }^{[22-25]}$ Given that the personnel is not aware of the recent guidelines and latest instructions are one of the primary reasons. The presence of information supported by common misunderstandings also contributes to this reality. All of these factors complicate the integration of the guidelines into clinical practice. The absence of an interdisciplinary commitment is another limitation in this context. We, at our meetings, explained recent manuals to the representatives of other departments, and thus, enabled the composition of appropriate algorithms for our hospital. The campaign "Why give 2 when I will do" is a campaign launched in the U.S.A. in 2015 with the aim to limit unnecessary use of blood. ${ }^{[26]}$ Informing the team periodically about such campaigns/new applications and their positive results and formulating measures was one of our aims during this 3-year period.

Significant amounts of time and effort are required to support a departmental and systemic change. The result suggests that although many clinicians are aware of the potential for the implementation of improved practices, there are many obstacles and challenges to overcome to implement the change.

In their retrospective case series, Pearse et al. ${ }^{[27]}$ stated the complexity of changing practice in the cardiac surgery unit and the difficulty of personal change. Pearse et al. reported that the key successful component of the quality initiative is an appropriately skilled project manager to facilitate the implementation process. They also suggested strong clinical leadership from the multidisciplinary team. Despite the presence of a multidisciplinary team in our study, we did not choose leaders for the team. However, we started to get prepared to take the first steps in this issue. The appointment of a leader with a demanding personality can guide the decision-making process and lead further steps about this issue.

Indeed, it is not too challenging to implement this procedure. Frank et al. ${ }^{\left[{ }^{[]}\right.}$integrated the PMB principles into a health system and simultaneously implemented them at five different hospitals. As a result, multiunit erythrocyte transfusion orders decreased from $39 \%$ to $20 \%$, and the rate of RBC, FFP and platelet transfusions significantly decreased. Additionally, Frank et al. demonstrated that anesthesiologists could be team leaders even in different hospitals and lead the success both inside and outside of the operating rooms.

\section{Limitations}

One of the major limitations of this study was that we did not analyze undergraduate and postgraduate education in detail. It is also possible to plan e-learning modules for all operating rooms and intensive care workers and to issue PBM certificates after these modules. In this way, continued learning and training can be integrated into clinical practice. One of the main problems in this context is to shift the conventional culture and ensure sustainability.

\section{CONCLUSION}

In conclusion, it is possible to limit the amount of blood product transfusion in patients undergoing cardiac surgery through a multidisciplinary team approach. In this study, however, we failed to limit transfusions, which we believe may be due to the increase of CPB and Cx times in years. The main problems seem to be that physicians do not adequately adhere to the guidelines; there are difficulties in planning continued training, and that the issues discussed during periodical training cannot be sufficiently conveyed into the clinical practice.

\section{Ethics Committee Approval}

This study was conducted in accordance with the Helsinki Declaration, and ethical approval was obtained from the institutional review board.

\section{Informed Consent}

Retrospective study.

Peer-review

Internally peer-reviewed.

Authorship Contributions

Concept: A.S., K.T.S.; Design: A.S., K.T.S.; Supervision: A.S., K.T.S.; Fundings: A.S., M.E., A.O., K.T.S.; Materials: A.S., M.E., A.O., K.T.S.; Data: A.S., M.E., A.O., K.T.S.; Analysis: A.S., M.E., A.O., K.T.S.; Literature search: A.S., M.E., A.O., K.T.S.; Writing: A.S., M.E., A.O., K.T.S.; Critical revision: A.S., K.T.S.

\section{Conflict of Interest}

None declared.

\section{REFERENCES}

1. Frank SM, Thakkar RN, Podlasek SJ, Ken Lee KH, Wintermeyer TL, Yang WW, et al. Implementing a Health System-wide Patient Blood Management Program with a Clinical Community Approach. Anesthesiology 2017;127:754-64. [CrossRef]

2. De Leon EM, Szallasi A. "Transfusion indication RBC (PBM-02)": gap analysis of a Joint Commission Patient BloodManagement Performance Measure at a community hospital. Blood Transfus 2014;12:187-90.

3. Zelinka ES, Brevig J, McDonald J, Jin R. The perfusionist's role in a collaborative multidisciplinary approach to blood transfusion reduction in cardiac surgery. J Extra Corpor Technol 2010;42:45-51.

4. Pearse BL, Smith I, Faulke D, Wall D, Fraser JF, Ryan EG, et al. Protocol guided bleeding management improves cardiac surgery patient outcomes. Vox Sang 2015;109:267-79. [CrossRef] 
5. Vuylsteke A, Pagel C, Gerrard C, Reddy B, Nashef S, Aldam P, et al. The Papworth bleeding risk score: a stratification scheme for identifying cardiac surgery patients at risk of excessive early postoperative bleeding. Eur J Cardio Thorac Surg 2011;39:924-30. [CrossRef]

6. Horvath KA, Acker MA, Chang H, Bagiella E, Smith PK, Iribarne A, et al. Blood transfusion and infection after cardiac surgery. Ann Thorac Surg 2013;95:2194-201. [CrossRef]

7. Bjursten H, Dardashti A, Ederoth P, Bronden B, Algotsson L. Increased long-term mortality with plasma transfusion after coronary artery bypass surgery. Intensive Care Med 2013;39:437-44. [CrossRef]

8. Galas FR, Almeida JP, Fukushima JT, Osawa EA, Nakamura RE, Silva CM, et al. Blood transfusion in cardiac surgery is a risk factor for increased hospital length of stay in adult patients. J Cardiothorac Surg 2013;8:54. [CrossRef]

9. Oruç AF, Karabulut ŞG, Mayadağhı A. Transfusion-dependent Graft-Versus-Host Disease: a role of blood irradiation in its prevention. J Kartal TR 2014;25:85-8. [CrossRef]

10. Meybohm P, Richards T, Isbister J, Hofmann A, Shander A, Goodnough LT, et al. Patient Blood Management Bundles to Facilitate Implementation. Transfus Med Rev 2017;31:62-71. [CrossRef]

11. Gross I, Seifert B, Hofmann A, Spahn DR. Patient blood management in cardiac surgery results in fewer transfusions and better outcome. Transfusion 2015;55:1075-81. [CrossRef]

12. Goodnough LT, Shieh L, Hadhazy E, Cheng N, Khari P, Maggio P. Improved blood utilization using real-time clinical decision support. Transfusion 2014;54:1358-65. [CrossRef]

13. Spahn DR, Moch H, Hofmann A, Isbister JP. Patient blood management: the pragmatic solution for the problems with blood transfusions. Anesthesiology 2008;109:951-3. [CrossRef]

14. Society of Thoracic Surgeons Blood Conservation Guideline Task Force; Ferraris VA, Brown JR, Despotis GJ, Hammon JW, Reece TB, Saha SP, et al. 2011 update to the Society of Thoracic Surgeons and the Society of Cardiovascular Anesthesiologists blood conservation clinical practice guidelines. Ann Thorac Surg 2011;91:944-82.

15. Likosky DS, Dickinson TA, Paugh TA. Blood Conservation-A Team Sport. J Extra Corpor Technol 2016;48:99-104.

16. Mazlan AM, Ayob Y, Hussein AR, Namasiwayam TK, Wan Mohammad WMZ. Factors influencing transfusion requirement in patients undergoing first-time, elective coronary artery bypass graft surgery. Asian J Transfus Sci 2017;11:95-101. [CrossRef]

17. Slaughter TF, Sreeram G, Sharma AD, El-Moalem H, East CJ, Greenberg CS. Reversible shear-mediated platelet dysfunction during cardiac surgery as assessed by the PFA- 100 platelet function analyzer. Blood Coagul Fibrinolysis 2001;12:85-93. [CrossRef]

18. Onorati F, Perrotti A, Reichart D, Mariscalco G, Della Ratta E, Santarpino G, et al. Surgical factors and complications affecting hospital outcome in redo mitral surgery: insights from a multicentre experience. Eur J Cardiothorac Surg 2016;49:127-33. [CrossRef]

19. Al-Sarraf N, Thalib L, Hughes A, Houlihan M, Tolan M, Young V, et al. Cross-clamp time is an independent predictor of mortality and morbidity in low- and high-risk cardiac patients. Int J Surg 2011;9:104-9.

20. Bielby L, Moss RL. Patient blood management and the importance of the Transfusion Practitioner role to embed this into practice. Transfus Med 2018;28:98-106. [CrossRef]

21. Whitney GM, Woods MC, France DJ, Austin TM, Deegan RJ, Paroskie A, et al. Reducing intraoperative red blood cell unit wastage in a large academic medical center. Transfusion 2015;55:2752-8.

22. Muñoz M, Gómez-Ramírez S, Kozek-Langeneker S, Shander A, Richards T, Pavía J, et al. 'Fit to fly': overcoming barriers to preoperative haemoglobin optimization in surgical patients. $\mathrm{Br} \mathrm{J}$ Anaesth 2015;115:15-24. [CrossRef]

23. Fischer DP, Zacharowski KD, Muller MM, Geisen C, Seifried E, Muller $\mathrm{H}$, et al. Patient blood management implementation strategies and their effect on physicians' risk perception, clinical knowledge and perioperative practice-the Frankfurt experience. Transfus Med Hemother 2015;42:91-7. [CrossRef]

24. Vamvakas EC. Reasons for moving toward a patient-centric paradigm of clinical transfusion medicine practice. Transfusion 2013;53:888901. [CrossRef]

25. Mbanya D. Barriers and enablers to introducing comprehensive patient blood management in the hospital. Biologicals 2012;40:205-8.

26. Podlasek SJ, Thakkar RN, Rotello LC, Fleury TA, Demski RJ, Ness PM, et al. Implementing a "Why give 2 when 1 will do?" Choosing Wisely campaign. Transfusion 2016;56:2164. [CrossRef]

27. Pearse BL, Rickard CM, Keogh S, Lin Fung Y. A retrospective explanatory case study of the implementation of a bleeding management quality initiative, in an Australian cardiac surgery unit. Aust Crit Care 2019;32:92-9. [CrossRef]

\section{Multidisipliner Ekip Yaklașımının Kan Transfüzyonu Üzerine Etkileri}

Amaç: Birleşik Komisyon ve Amerikan Tabipler Birliği tarafından toplanan Performans İyileştirme Konsorsiyumu, kan transfüzyonlarının modern tıbbın ilk beş aşııı kullanımı arasında olduğunu bildirmiştir. Kan transfüzyonunun optimal yönetimi, hasta güvenliğini artıran en önemli faktörlerden biridir ve bu anlamda tüm dünyada özel eğitimler artmaktadır. Bu geriye dönük kohort çalışmasında amacımız, periyodik konsensus toplantılarının ve perioperatif kan transfüzyonu üzerine yapılan eğitimin, farklı tıp dallarından oluşan bir ekip tarafından araştırılmasıdır.

Gereç ve Yöntem: Kan transfüzyonu gereksinimi bulunan, kalp cerrahisi geçiren 18 yaş üstü hastalar çalışmaya dahil edildi. Transfüzyonlar kümülatif olarak hesaplandı, yıllara göre değişim, yan etkiler ve transfüzyon ile ilişkili komplikasyonlar belirlendi. Hastaların kardiyak rezervleri, laboratuvar değerleri, antikoagülan ilaç kullanım sıklı̆ı, transfüzyon miktarı, komplikasyonlar ve mortalite oranları kaydedildi. Ameliyat tipleri, revizyon oranı, yoğun bakım süresi ve hastanede kalış süresi kaydedildi.

Bulgular: Hastaların yaş, VKi, komorbidite oranı, antimikrobiyal ilaç kullanımı yıllara göre farklıık göstermemiştir ( $p>0.05$ ). Yoğun bakım ve hastanede kalış süresi, kanama miktarı ve mortalite oranı istatistiksel olarak farklı değildi ( $p>0.05)$. 2016 yılında $C B P$ ve $C X$ zamanı, 2014 ve 20I5'e göre anlamlı olarak daha yüksekti $(p<0.05)$. Kan transfüzyonu miktarı anlamlı olarak farklılık göstermedi $(p>0.05)$. Ayrıca 2014 sonrası trombosit transfüzyonunda artış gözlendi. Ameliyat öncesi dönemde Hb, Htc, trombosit ve INR'deki değişiklik anlamlı olarak farklılık göstermedi.

Sonuç: Çalışmamızda restriktif kan ürünü kullanımı ile ilgili eğitimin kan transfüzyonu üzerinde pozitif bir etkiye sahip olmadığı gösterilmiştir. Bilginin klinik ortama yeterince aktarılması konusunda zorluklar olduğu ortaya konulmuştur.

Anahtar Sözcükler: Eğitim; kan transfüzyonu; kardiyak cerrahi işlemler. 